KS. JAN DYDUCH

Wydział Prawa Kanonicznego

Uniwersytetu Papieskiego Jana Pawła II w Krakowie

\title{
ROLA KODEKSU PRAWA KANONICZNEGO 1983 W REALIZOWANIU MISJI KOŚCIOLA
}

Treść: Wstęp. - 1. Kościół - Lud Boży wspólnotą zbawczą. - 2. Ewangelizacja ukazywaniem drogi zbawienia. - 3. Posługa uświęcania w perspektywie „salus animarum". - Zakończenie.

\section{Wstęp}

Kodeks Prawa Kanonicznego (= KPK) został promulgowany przez Jana Pawła II dnia 25 stycznia 1983 r. Vacatio legis trwała przez prawie dziesięć miesięcy do początku adwentu 1983 r., tj. do 27 listopada 1983 roku. Zatem przywołany Kodeks zaczął obowiązywać 27 listopada 1983 roku. W roku 2013, dokładnie 27 listopada mija 30 lat, od kiedy KPK reguluje działalność Kościoła katolickiego. Trzeba dodać, iż tę działalność reguluje także Kodeks Kanonów Kościołów Wschodnich $(=\mathrm{KKKW})$. W kontekście tej rocznicy warto postawić pytanie: czy KPK nadal służy zbawczej misji Kościoła? Nie chodzi tu o jakieś podsumowanie, co Kodeks wniósł w życie Kościoła, ale jedynie tylko o ukazanie jego aktualnej roli w spełnianiu misji Kościoła. Niniejszy artykuł zamierza więc, przynajmniej w zarysie, zaprezentować, że KPK pomaga realizować tradycyjną zasadę: „Salus animarum suprema lex esto" - Zbawienie dusz winno być najwyższym prawem w Kościele" (por. kan. 1752 KPK).

\section{Kościół - Lud Boży wspólnotą zbawczą}

Jednym z podstawowych zagadnień, które postawił Sobór Watykański II było pytanie: „Ecclesia, quid dicis de seipsa?” (Kościele, 
co mówisz sam o sobie?). Jedną z odpowiedzi na to pytanie było soborowe nauczanie o wspólnocie Ludu Bożego: „Albowiem wierzący w Chrystusa, odrodzeni nie z nasienia skazitelnego, lecz z nieskazitelnego przez słowo Boga żywego, nie z ciała, lecz z wody i Ducha Świętego, ustanowieni są w końcu jako wybrane plemię, królewskie kapłaństwo, naród święty, lud Bogu na własność przeznaczony, który był nie-ludem, teraz zaś jest Ludem Bożym"1. Ten lud jest ustanowiony przez Chrystusa jako wspólnota (communio) życia, miłości i prawdy, jest posłany do świata jako narzędzie zbawienia dla wszystkich ludzi².

Idea wspólnoty Ludu Bożego nie była obca teologii i kanonistyce w okresie przedsoborowym ${ }^{3}$. Szeroko została ona opracowana i wyjaśniona $\mathrm{w}$ okresie posoborowym. Publikacje na ten temat ukazują potrzebę powiązania prawa kanonicznego z naturą Kościoła, w której winno być zakorzenione 4 . Soborowa nauka o Kościele znajduje odzwierciedlenie w KPK. Pisze Jan Paweł II w konstytucji promulgującej Kodeks: „Zatem w jakiś sposób ten nowy Kodeks może być pojmowany jako wielki pas transmisyjny przenoszący na język kanonistyczny tę doktrynę, mianowicie soborową eklezjologię"5. Kodeks ten określa wspólnotę Ludu Bożego następująco: „§ 1. Wiernymi są ci, którzy przez chrzest wszczepieni w Chrystusa zostali ukonstytuowani Ludem Bożym i stawszy się z tej racji na swój sposób uczestnikami kapłańskiego, prorockiego i królewskiego posłannictwa Chrystusa, zgodnie z własną każdego pozycją, są powołani do wypełniania misji, jaką Bóg powierzył pełnić Kościołowi w świecie. §2. Ten Kościół, ukonstytuowany i uporządkowany na tym świecie jako społeczność, trwa

1 Konstytucja soborowa, „Lumen gentium” (= KK), n. 9.

2 Por. tamże, n. 9.

${ }^{3}$ Por. E. ŁukAszyK, Pojęcie Kościoła jako Ludu Bożego w eklezjologii Vaticanum II, Roczniki Teologiczno-Kanoniczne, 16(1969) z. 2, s. 41-62; Y. Congar, Kościól jako Lud Boży, Concilium, 1-10, 1965/6, Poznań-Warszawa 1968, s. 13-27.

4 Por. R. Sobański, Kościól - prawo - zbawienie, Katowice 1979; M. Żurowski, Uprawnienie do wspóluczestniczenia $w$ kościelnej wspólnocie wspólnot, Ius ad communionem, Warszawa 1979.

5 Konstytucja „Sacrae disciplinae leges”, 25 I 1983, Kodeks Prawa Kanonicznego, przekład polski, Poznań 1984, s. 13. 
w Kościele katolickim, kierowanym przez następcę Piotra i biskupów we wspólnocie z nimi" (kan. 204).

Przywołany kanon zawiera bogatą treść teologiczną, która została wyrażona w normie kanonicznej. Określa wspólnotę wiernych ukształtowaną jako Lud Boży. Ten Lud Boży stanowi rzeczywistość złożoną, mianowicie rzeczywistość Bosko-ludzką. Zrasta się w niej pierwiastek boski i ludzki, nadprzyrodzony i doczesny. Uobecnia się tam wspólnota wiary, nadziei i miłości, wspólnota Boga z ludźmi i ludzi między sobą. Ta nadprzyrodzona wspólnota znajduje swój wyraz we wspólnocie widzialnej ${ }^{6}$. Elementem istotnym dla poszczególnych członków Ludu Bożego jest sakrament chrztu. Jest on rzeczywistością widzialną, sprawiającą niewidzialne, nadprzyrodzone skutki.

Ten lud Boży jest ludem kapłańskim. Naucza Vaticanum II: „Kapłaństwo zaś wspólne wiernych i kapłaństwo służebne czyli hierarchiczne, chociaż różnią się istotą, a nie tylko stopniem są sobie jednak wzajemnie przyporządkowane: jedno i drugie bowiem we właściwy sobie sposób uczestniczy w jedynym kapłaństwie Chrystusa"7. Zapodmiotowanie kapłaństwa wspólnego, zwanego także powszechnym czy chrzcielnym i kapłaństwa służebnego w jedynym kapłaństwie Chrystusa sprawia, że są to dwie rzeczywistości różne, ale nie przeciwstawne, które nie są rozdzielone. Są to dwie rzeczywistości, między którymi zachodzi ścisła łącznośś ${ }^{8}$.

Wszyscy obdarzeni kapłaństwem wspólnym uczestniczą w ofiarowaniu Eucharystii, w przyjmowaniu sakramentów, a przez modlitwę, umartwienie i czynną miłość stają się świadkami świętości wspólnoty Ludu Bożego?. Te zadania wyraża KPK: „Wszyscy wierni chrześcijanie zgodnie z własną pozycją powinni prowadzić święte życie i przyczyniać się do wzrostu Kościoła, oraz ustawicznie swoimi siłami

${ }^{6}$ Por. R. SoBAŃsKi, Kościól - jego konstytucja i prawo w tajemnicy zbawienia, Analecta Cracoviensia, 8(1976)228; L. MoreIRA NEVES, Gli stati griuridici delle persone nella Chiesa, Presupposti teologici, Monitor Ecclesiasticus, 106(1981)368-369.

7 KK, n. 10.

${ }^{8}$ Por. L. BALter, Kapłan ministerialny w kapłańskiej wspólnocie Ludu Bożego, w: W kierunku prawdy, red. B. Bejze, Warszawa 1976, s. 184.

9 Por. KK, n. 10. 
wspierać rozwój jego świętości” (kan. 210). KPK wyraża także szczególne zadania obdarowanych kapłaństwem służebnym: „Na mocy ustanowienia Bożego, przez sakrament kapłaństwa niektórzy spośród wiernych, naznaczeni w nim niezatartym charakterem, są ustanawiani świętymi szafarzami: są oni mianowicie konsekrowani i przeznaczeni, ażeby - każdy odpowiednio do swojego stopnia, wypełniając w osobie Chrystusa-Głowy zadania nauczania, uświęcenia i kierowania - byli pasterzami Ludu Bożego" (kan. 1008). Ten kanon został zmieniony przez papieża Benedykta XVI, jak również następny 1009 ściśle z nim związany ${ }^{10}$. Zmieniony kanon 1008 brzmi: „Na mocy ustanowienia Bożego, przez sakrament kapłaństwa, niektórzy spośród wiernych, naznaczeni w nim niezatartym charakterem, są ustanawiani świętymi szafarzami; są oni mianowicie konsekrowani i przeznaczeni, ażeby każdy odpowiednio do swojego stopnia, nowym i szczególnym tytułem służył Ludowi Bożemu”. Kan. 1009 został uzupełniony nowym, trzecim paragrafem: „Ci, którzy zostali ustanowieni biskupami lub kapłanami otrzymują misję i zdolność działania w osobie Chrystusa-Głowy (in persona Christi), natomiast diakoni otrzymują moc służenia Ludowi Bożemu w diakonii liturgii, słowa i miłości”.

Wprowadzone, wyżej przywołane zmiany, bardziej uwypuklają hierarchiczny ustrój zbawczej wspólnoty Ludu Bożego-Kościoła. O jego hierarchicznej strukturze naucza Sobór Watykański II, w szczególności w III rozdziale konstytucji „Lumen gentium”, noszącym tytuł „O hierarchicznym ustroju Kościoła, a w szczególności o episkopacie”. Rozpoczyna się on następująco: „Celem pasterzowania Ludowi Bożemu i jego nieustannego pomnażania Chrystus Pan ustanowił w swoim Kościele rozmaite posługi, które nakierowane są na dobro całego Ciała"11. Od początku istnienia Kościół charakteryzuje się hierarchicznością. Podstawowa konstytucja hierarchiczna Ludu Bożego, pochodząca od jego Założyciela Jezusa Chrystusa, była w ciągu wieków uzupełniana przez potrzeby Kościoła. Odzwierciedleniem tej tradycji, jak również nauczania Vaticanum II, są normy KPK, znajdujące się w jego Księ-

\footnotetext{
${ }^{10}$ Motu proprio „Omnium in mentem”, 26 X 2009, AAS 102(2010)8-10.

${ }^{11} \mathrm{KK}, \mathrm{n} .18$.
} 
dze II, w obszernej części II „Hierarchiczny ustrój Kościoła” liczącej 242 kanony. Kanon wstępny tej części brzmi: „Jak z ustanowienia Pańskiego święty Piotr i pozostali Apostołowie stanowią jedno kolegium, w podobny sposób są złączeni między sobą Biskup Rzymski, następca Piotra i biskupi, następcy Apostołów" (kan. 330 KPK).

W całkowitej harmonii z hierarchicznym ustrojem Kościoła jest, pochodząca także z woli Jezusa, podstawowa równość wszystkich jego członków. Naucza Vaticanum II: „Jeden jest zatem wybrany Lud Boży: jeden jest Pan, jedna wiara, jeden chrzest; wspólna jest godność członków wynikająca z ich odrodzenia w Chrystusie, wspólna łaska synów, wspólne powołanie do doskonałości, jedno zbawienie i niepodzielna miłość" ${ }^{12}$. Ta podstawowa równość w Kościele nie sprawia tego, że staje się on wspólnotą demokratyczną, nie jest bowiem ani demokracją, ani monarchią; sprawia natomiast w nim jedność i różnorodność. O fundamentalnej jedności wspólnoty Ludu Bożego mówi KPK: „Z racji odrodzenia w Chrystusie wszyscy wierni są równi co do godności i działania na skutek czego każdy, zgodnie z własną pozycją i zadaniem, współpracuje w budowaniu Ciała Chrystusowego" (kan. 208). Lud Boży, stanowiący wspólnotę kapłańską, ukształtowaną hierarchicznie, prowadzi do zbawienia przez działalność ewangelizacyjną, posługę uświęcania i pasterzowania, posługując się porządkiem prawnym.

\section{Ewangelizacja ukazywaniem drogi zbawienia}

Naucza Vaticanum II: „Święty Lud Boży uczestniczy także w prorockiej funkcji Chrystusa, szerząc o Nim żywe świadectwo, przede wszystkim życiem wiary i miłości i składając Bogu ofiarę chwały, owoc warg, które wyrażają Jego imię"13. Odpowiedzialność za ewangelizację ponosi cały Lud Boży, który uczestniczy w posłudze prorocko-nauczycielskiej Chrystusa. To zadanie wypełniają członkowie wspólnoty Ludu Bożego przez świadectwo życia z wiary i świadectwo słowa. Naucza dalej Vaticanum II: „Kościół powstał po to, by poprzez

\footnotetext{
12 Tamże, n. 32.

13 Tamże, n. 12.
} 
rozszerzanie królestwa Chrystusa po całej ziemi ku chwale Boga Ojca, uczynić wszystkich ludzi uczestnikami zbawczego odkupienia i by przez nich cały świat rzeczywiście został skierowany ku Chrystusowi" "14. Rozszerzanie królestwa Chrystusowego po całej ziemi nie jest możliwe bez włączenia się w ewangelizację całego Ludu Bożego. To nauczanie podejmuje adhortacja „Evangelii nuntiandi”"15. Naucza Paweł VI: „Obowiązek ewangelizacji należy uważać za łaskę i właściwe powołanie Kościoła; wyraża on najprawdziwszą jego właściwość. Kościół jest dla ewangelizacji..."16.

Wszyscy członkowie wspólnoty Ludu Bożego są dla ewangelizacji i mają podjąć zadania powierzone im przez Jezusa Chrystusa: „Idźcie więc i nauczajcie wszystkie narody...” (Mt 28, 19). Zobowiązuje ich do tego także KPK: „Wszyscy wierni mają obowiązek i prawo współpracy w tym, aby Boże przepowiadanie zbawienia rozszerzało się coraz bardziej na wszystkich ludzi każdego czasu i całego świata" (kan. 211). Przepowiadanie Ewangelii jest obowiązkiem i prawem wrodzonym Kościoła (ius nativum), to znaczy niezależne od jakiejkolwiek władzy ludzkiej, (por. kan. 747 §1 KPK). Dlatego Kościół broni swojego prawa do ewangelizacji i stara się je zabezpieczyć przed ingerencją władzy świeckiej. Powszechnie stosowanym tutaj narzędziem są umowy zawierane między Stolicą Apostolską a poszczególnymi państwami. Sprawę tę Konkordat Polski z 1993 r. podejmuje już w preambule: ,...postanowiły zawrzeć niniejszy Konkordat, przy czym Rzeczpospolita Polska uwzględniła swe zasady konstytucyjne i ustawy, a Stolica Apostolska - dokumenty Soboru Watykańskiego II dotyczące wolności religijnej i stosunków między Kościołem a wspólnotą polityczną oraz przepisy prawa kanonicznego". Dalsze, szczegółowe regulacje konkordatowe dotyczą poszczególnych dziedzin wchodzących w misję prorocką Kościoła ${ }^{17}$.

${ }^{14}$ Dekret soborowy „Apostolicam actuositatem” (= DA), n. 2.

${ }^{15}$ PAwel VI, 8 XII 1975, AAS 58(1976)5-76; tłum. polskie, Posoborowe Prawodawstwo Kościelne, zebrał i przetłumaczył ks. E. Sztafrowski (= PPK), t. VIII, z. 1, s. 117-241.

${ }^{16}$ Tamże, s. 131.

${ }^{17}$ Szerzej na ten temat, por. J. Dyduch, Potrójna misja Kościoła w świetle Konkordatu Polskiego 1993 roku, Annales Cannonici, 7(2011)89. 
Podstawowymi formami ewangelizacji są: Przepowiadanie słowa Bożego i nauczanie katechetyczne. Nauczanie soborowe zaznacza, że przepowiadaniem słowa kierują biskupi, którzy także zobowiązani są je przepowiadać, ich pomocnikami są prezbiterzy i diakoni, a także uczestniczą w nim zakonnicy i wierni świeccy ${ }^{18}$. Myśli te podejmuje KPK, normując przepisy dotyczące przepowiadania w Kościele (por. kan. 762, 763, 764, 765, 766). Zobowiązuje on przepowiadających: „Głosiciele słowa Bożego powinni przedstawiać wiernym przede wszystkim to, w co należy wierzyć i co trzeba czynić dla chwały Bożej i zbawienia ludzi” (kan. $768 \S 1$ ).

Istotne znaczenie w posłudze prorockiej ma katechizacja. Tak ją określa nauczanie soborowe: „W wypełnianiu swojego obowiązku wychowawczego Kościół, zapobiegliwy o wszystkie odpowiedzialne środki, troszczy się szczególnie o te, które są mu właściwe, a z których pierwszym jest katechizacja; ona to oświeca i wzmacnia wiarę, karmi życie według ducha Chrystusowego, doprowadza do świadomego i czynnego uczestniczenia w misterium liturgicznym i pobudza do działalności apostolskiej”"19. O katechezę winien się troszczyć cały Lud Boży: „Troska o katechezę, pod kierownictwem prawowitej władzy kościelnej, należy do wszystkich członków Kościoła, w części każdemu właściwej" (kan. 774 §1 KPK).

Kilka lat wcześniej, przed promulgowaniem KPK, ukazała się obszerna posynodalna adhortacja apostolska o katechizacji, która całościowo omawia tę ważną sprawę dla Kościoła. Stawia ona ogólną tezę, że każdy w Kościele potrzebuje katechizacji i każdy jest za nią odpowiedzialny ${ }^{20}$. Odpowiedzialność ta jest zróżnicowana. Szczególną odpowiedzialność ponoszą biskupi, duszpasterze, rodzice, katecheci i nauczyciele (por. kan. 775-778) ${ }^{21}$.

\footnotetext{
${ }^{18}$ Por. KK , n. 24-25, 28-29, 35.

${ }^{19}$ Deklaracja soborowa „Gravissimum educationis” (= DWCh), n. 4.

${ }^{20}$ JAN PAWEŁ II, Adhortacja „Catechesi tradendae”, 16 X 1979, w: Adhortacje apostolskie Ojca Świętego Jana Pawła II, Kraków 1996, n. 45.

${ }^{21}$ Por. J. Dyduch, Postuga nauczania $w$ świetle postanowień Konkordatu 1993, w: Konkordat 1993, Dar i zadanie dla Kościoła w Polsce, Kraków 1998, s. 64-73.
} 
Nauczanie Vaticanum II podkreśla aktualność działalności misyjnej Kościoła wobec ludów, które nie znają Ewangelii (missio ad gentes): „Stąd też Kościół za swoje uznaje słowa Apostoła: ,Biada mi bowiem, gdybym nie głosił Ewangelii', i dlatego nieustannie rozsyła zwiastunów, dopóki nie powstaną nowe Kościoły i nie zaczną same prowadzić dzieła ewangelizacji”22. Całościowy program działalności misyjnej wobec ludów i narodów nie znających Ewangelii prezentuje dekret soborowy „Ad gentes divinitus”. Na jego podstawie zostały skonstruowane normy KPK dotyczące misyjnej działalności Kościoła, za którą jest odpowiedzialny cały Lud Boży. Określona została tam działalność misyjna w sposób następujący: „Działalność misyjna we właściwym tego słowa znaczeniu, dzięki której zaszczepia się Kościół w narodach i wspólnotach, w których jeszcze się nie zakorzenił, jest prowadzona przez Kościół, zwłaszcza poprzez wysyłanie zwiastunów Ewangelii, dopóki nowe Kościoły nie zostaną w pełni ukonstytuowane...” (kan. $786 \mathrm{KPK})$.

Szczególną rolę w ewangelizacji odgrywa rodzina. Naucza Sobór Watykański II: „Dlatego rodzina chrześcijańska, jako że bierze początek z małżeństwa, które jest obrazem przymierza miłości Chrystusa i Kościoła i uczestnictwem w nim, ma objawiać wobec wszystkich żywą obecność zbawiciela w świecie i prawdziwą naturę Kościoła...."23. Rodzina jest poniekąd odblaskiem Kościoła, zwana w nauczaniu soborowym „niejako domowym kościołem”, w którym rodzice słowem i przykładem powinni być dla swoich dzieci pierwszymi zwiastunami wiary $^{24}$. Rodzina jest wspólnotą ewangelizacyjną, w której rolę ewangelizatorów spełniają, przede wszystkim, rodzice, aczkolwiek także oni mogą być ewangelizowani przez swoje dzieci zwłaszcza dorosłe ${ }^{25}$. Rolę rodziców w ewangelizowaniu wyrażającym się ich działalnością wychowawczą uwypukla KPK: „,Rodzice, ponieważ dali dzieciom życie, mają bardzo poważny obowiązek i prawo ich wychowania. Stąd

${ }^{22} \mathrm{KK}$, n. 17.

${ }^{23}$ Konstytucja soborowa „Gaudium et spes”, (=KDK), n. 48.

${ }^{24}$ Por. KK, n. 11.

${ }^{25}$ Por. J. Dyduch, Obowiąki i prawa wiernych świeckich w prawodawstwie soborowym, Kraków 1985, s. 239-242. 
też na pierwszym miejscu do chrześcijańskich rodziców należy troska o chrześcijańskie wychowanie dzieci, zgodne z nauką przekazywaną przez Kościół” (kan. 226 §2). Wychowanie dzieci przez rodziców, w szczególności ich katolickie wychowanie, jest sprawą tak ważną w ewangelizacyjnej działalności Kościoła, iż prawodawca, w różnych aspektach, wraca do niej jeszcze kilka razy w Kodeksie (kan. 793 §1, $774 \S 2,835 \S 4,1136)$.

W ewangelizacyjnej działalności, w szczególności w ewangelizowaniu nowego pokolenia mają udział szkoły różnego stopnia i rodzaju. Naucza Vaticanum II: „Spośród wszystkich środków pomocniczych wychowania szczególne znaczenie ma szkoła, ponieważ mocą swego posłannictwa wytrwale i troskliwie kształtuje władze umysłowe, rozwija zdolność wydawania prawidłowych sądów, wprowadza w dziedzictwo kultury wytwarzanej przez minione pokolenia, kształci poczucie wartości, przygotowuje do życia zawodowego..."26. Szkoła stanowi poniekąd centrum, którym są zainteresowane i uczestniczą w jego działalności: rodziny, nauczyciele, różne organizacje kulturalne, obywatelskie, religijne, Kościół katolicki, inne wspólnoty religijne, a także w jakiś sposób cała wspólnota ludzka. Nauczanie soborowe sporo miejsca poświęca szkole katolickiej ${ }^{27}$. Przywołane nauczanie soborowe znajduje odzwierciedlenie w KPK, który stwierdza: „Wśród środków wychowania wierni powinni bardzo cenić szkoły, które są dla rodziców główną pomocą w wypełnianiu obowiązku wychowania" (kan. 796 §1). Następnie formułuje kanony, które zajmują się szkołami w ogóle, poświęcając należne miejsce szkole katolickiej (por. kan. 797-806).

Odrębne nauczanie soborowe traktuje szkoły wyższe: „Również troskliwą opieką Kościół otacza szkoły wyższe, zwłaszcza uniwersytety i fakultety"28. Również ogłasza prawo Kościoła do swobodnego zakładania i prowadzenia szkół każdego rodzaju i stopni ${ }^{29}$. Tę ideę

\footnotetext{
${ }^{26}$ DWCh, n. 5.

${ }^{27}$ Por. tamże, n. 5-9.

${ }^{28}$ Tamże, n. 10.

${ }^{29}$ Por. tamże, n. 8.
} 
soborową podejmuje KPK: „Kościół ma prawo zakładania uniwersytetów i kierowania nimi. Przyczyniają się one do pogłębienia kultury ludzkiej i pełniejszego rozwoju osoby ludzkiej, a także do wypełniania posługi nauczania w Kościele" (kan. 807).

Niezwykłą rolę w ewangelizacji odgrywają środki przekazu, których rozwój w ostatnich czasach jest imponujący. Naucza Sobór Watykański II: „Kościół katolicki został ustanowiony przez Chrystusa Pana, aby nieść zbawienie wszystkim ludziom i z tego względu zobowiązany jest do głoszenia Ewangelii, dlatego uznaje on, że do jego obowiązków należy głoszenie orędzia zbawienia, również za pomocą środków społecznego przekazu i pouczanie ludzi o właściwym ich wykorzystywaniu"30. To nauczanie odzwierciedla KPK, który stwierdza, że Kościół ma prawo korzystać w swej misji ze środków przekazu. Należy przepajać je duchem ludzkim i chrześcijańskim, zaś wierni, którzy biorą udział w ich organizowaniu mają pomagać, aby one były narzędziem ewangelizacji (por. 822). Zarówno od Vaticanum II, jak i od promulgowania Kodeksu nastąpił znaczny rozwój środków przekazu, zwłaszcza ogromne możliwości stwarza Internet. Papieska Rada ds. Środków Społecznego Przekazu wydała dwa dokumenty na ten temat: „Etyka w Internecie”"31, „Kościół a Internet”32. Przestrzeń internetowa przenika świat współczesny, a Kościół i jego instytucje aktywnie wykorzystują Internet w duszpasterstwie ${ }^{33}$.

Współczesna sytuacja religijności i wiary, zwłaszcza wobec szerzenia się obojętności religijnej, sekularyzmu i ateizmu w krajach i narodach, w których niegdyś kwitła religia i życie chrześcijańskie, zrodziły potrzebę nowej ewangelizacji. Polega ona na głoszeniu tej samej Ewangelii Jezusa Chrystusa, ale z nowym dynamizmem, nowym zapałem, i nowymi bardziej skutecznymi metodami. Terminu „nowa ewangelizacja” w nauczaniu po raz pierwszy użył Jan Paweł II w ho-

${ }^{30}$ Dekret soborowy, ,Inter mirifica”, n. 3.

${ }^{31} 22$ II 2002, Biuletyn KAI, 11, 17 III 2002, s. 31-35.

3222 II 2002, Biuletyn KAI, 10, 10 III 2002, s. 31-35.

${ }^{33}$ Bardzo szeroko na ten temat: A. Domaszk, Możliwości zastosowania Internetu w misji Kościoła katolickiego, Kraków 2013. 
milii wygłoszonej w Nowej Hucie Mogile 9 czerwca 1979 r. podczas I Pielgrzymki do Ojczyzny ${ }^{34}$. Potem często wracał do tej problematyki.

Tę ideę kontynuował Papież Benedykt XVI, który ustanowił Papieską Radę ds. Krzewienia Nowej Ewangelizacji jako odrębną dykasterię Kurii Rzymskiej ${ }^{35}$. Jej zadanie jest następujące: „Rada realizuje swoje cele zarówno pobudzając do refleksji nad tematami związanymi z nową ewangelizacją, jak i określając i propagując formy i narzędzia służące do jej realizacji”’36.

\section{Posługa uświęcania w perspektywie „salus animarum"}

Kościół wykonuje misję zbawczą poprzez całą swoją działalność. Jego misja pasterska i misja prorocka, o czym wyżej mówiliśmy, ma jako zasadniczy cel prowadzenie do świętości i do zbawienia. Szczególnym charakterem zbawczym naznaczona jest jego posługa uświęcania, zwana także posługą kapłańską, gdyż, jak wyżej zaznaczyliśmy, wspólnota Ludu Bożego, jest ludem kapłańskim. Naucza Vaticanum II: „Słusznie zatem uważa się liturgię za wypełnianie kapłańskiej funkcji Jezusa Chrystusa. W niej przez znaki dostrzegalne wyraża się i w sposób właściwy dla poszczególnych znaków dokonuje się uświęcenia człowieka, a Mistyczne Ciało Jezusa Chrystusa, to jest Głowa ze swoimi członkami, sprawuje pełny kult publiczny"37. W celebracji liturgicznej spotyka się działanie Jezusa Chrystusa z działalnością Kościoła - wspólnotą zbawczą. Stąd Kościół, jego kompetentna władza wyznacza osoby do czynności liturgicznych, które dokonują się w sposób określony przez Kościół i w jego imieniu. To nauczanie soborowe wyraża KPK: „Zadanie uświęcania wypełnia Kościół w szczególny sposób przez świętą liturgię, która też jest sprawowaniem kapłańskiego zadania Jezusa Chrystusa; w niej poprzez znaki widzialne ukazuje się i w sposób właściwy każdemu dokonuje się uświęcenie ludzi,

\footnotetext{
${ }^{34}$ Pielgrzymka Jana Pawła II do Polski, Poznań-Warszawa 1979, s. 192.

${ }^{35}$ Motu proprio „Ubicumque et semper”, 21 IX 2010, L'Osservatore Romano, wyd. pol. 32(2011) nr. 1, s. 11-13.

${ }^{36}$ Tamże, s. 13.

${ }^{37}$ Konstytucja soborowa „Sacrosanctum Concilium” (= KL), n. 7.
} 
a także przez Mistyczne Ciało Jezusa Chrystusa, to znaczy Jego Głowa i członki, jest sprawowany cały publiczny kult Boży" (kan. 834, §1).

Vaticanum II, nauczając o powszechnym powołaniu do świętości, zobowiązuje cały Kościół do uczestnictwa w posłudze uświęcania i czyni go odpowiedzialnym za wzrost świętości jego członków. Przewodnią rolę odgrywają tutaj biskupi, którzy zarówno słowem jak i przykładem winni spełniać służbę biskupią (servitium episcopale). W tym dziele pomagają im kapłani i diakoni. Wierni świeccy przez spełnianie obowiązków chrześcijańskich uczestniczą w posłudze uświęcania $^{38}$. Te soborowe wskazania podejmuje KPK. Stwierdza on, że posługę uświęcania sprawują biskupi, którzy są głównymi szafarzami Bożych tajemnic oraz moderatorami, promotorami i stróżami życia liturgicznego. W wykonywaniu zadań uświęcania, pod władzą biskupa, uczestniczą prezbiterzy, którzy są konsekrowani do sprawowania kultu Bożego i uświęcania wiernych. Własny udział w tym dziele mają diakoni a także wierni świeccy. Szczególne zadania uświęcające podejmują rodzice, prowadząc w duchu chrześcijańskim życie małżeńskie oraz przez katolickie wychowanie potomstwa (por. kan. $835 \mathrm{KPK}$ ).

Kościół szczególną troską otacza kult liturgiczny i precyzuje dokładnie jego organizację we wspólnocie Ludu Bożego (por. kan. 838 KPK). Docenia także kult prywatny i pobożność ludową, przez którą również Kościół wypełnia posługę uświęcania (por. kan.839, §1 KPK). W tym względzie prawodawstwo kościelne idzie po linii nauczania Vaticanum II: „Usilnie się zaleca nabożeństwa chrześcijańskiego ludu, pod warunkiem, że sprawuje się je zgodnie z przepisami i zasadami Kościoła, zwłaszcza gdy odbywają się na zlecenie Stolicy Apostolskiej"39. Należy je uporządkować tak, aby były zgodne ze świętą liturgią i do niej przygotowywały ${ }^{40}$.

Wśród kultu liturgicznego wiodące miejsce zajmują sakramenty święte, które jednoczą wierzących z Jezusem Chrystusem. Naucza Sobór: „Życie Chrystusa rozlewa się w tym Ciele (Ciało Mistyczne)

\footnotetext{
${ }^{38}$ Por. KK, n. 39-42.

${ }^{39}$ KL, n. 13.

${ }^{40}$ Por. tamże, n. 13.
} 
na wierzących, którzy przez sakramenty jednoczą się w sposób tajemniczy i rzeczywisty z umęczonym i uwielbionym Chrystusem" "41. Tak też przez sakramenty spełnia się dzieło uświęcenia i zbawienia dokonane przez życie, śmierć i Zmartwychwstanie Jezusa ${ }^{42}$. Nauczanie soborowe odzwierciedla KPK: „Sakramenty Nowego Testamentu, ustanowione przez Chrystusa i powierzone Kościołowi jako czynności Chrystusa i Kościoła są znakami oraz środkami przez które wyraża się i wzmacnia wiarę, oddawany jest Bogu kult i dokonuje się uświęcenie człowieka. $Z$ tej racji w najwyższym stopniu przyczyniają się do wprowadzenia, umocnienia i zamanifestowania kościelnej wspólnoty. Dlatego w ich sprawowaniu święci szafarze oraz pozostali wierni powinni okazać najwyższy szacunek i należną pilność" (kan. 840).

Sobór Watykański II, nawiązując do wielowiekowej tradycji Kościoła, naucza o poszczególnych sakramentach świętych i pozostałych aktach kultu Bożego, a KPK w oparciu o nie formułuje przepisy prawne ich dotyczące. Sprawa ta wymaga odrębnego omówienia. Wśród sakramentów wiodące miejsce zajmuje Eucharystia, która jest centrum życia sakramentalnego. Naucza Vaticanum II: „Nasz Zbawiciel podczas Ostatniej Wieczerzy, tej nocy, kiedy został wydany, ustanowił eucharystyczną Ofiarę swojego Ciała i Krwi, aby w niej na całe wieki aż do swego przyjścia, utrwalić ofiarę krzyża i tak powierzyć Kościołowi, umiłowanej Oblubienicy, pamiątkę swej Męki i Zmartwychwstania"ł3. Ofiara Chrystusa jest szczytem, do którego zmierza działalność Kościoła i źródłem jego mocy ${ }^{44}$. Dzięki niej Lud Wierny, w swej drodze do zbawienia, może posilać się Ciałem i Krwią Jezusa i adorować Go rzeczywiście obecnego w Najświętszym Sakramencie ${ }^{45}$. To nauczanie soborowe przejmuje KPK: „Najbardziej czcigodnym sakramentem jest Najświętsza Eucharystia, w której sam Chrystus Pan jest obecny, ofiaruje się oraz jest spożywany i dzięki której Kościół ustawicznie żyje i wzrasta. Ofiara eucharystyczna, pamiątka Śmierci i Zmartwychwsta-

\footnotetext{
${ }^{41} \mathrm{KK}$, n. 7.

${ }^{42}$ Por. KL, n. 6-7, 14.

${ }^{43}$ Tamże, n. 47.

${ }^{44}$ Por. tamże, n. 10.

${ }^{45}$ Por. KK, n. 3, 11, 17, 26.
} 
nia Pana, w której uwiecznia się Ofiara Krzyża, jest szczytem i źródłem całego kultu oraz życia chrześcijańskiego... kan. 897).

Do sprawowania kultu Bożego i do urzeczywistniania pobożności wiernych przeznacza Kościół szczególnym poświęceniem czy błogosławieństwem niektóre miejsca, które nazywa świętymi. Są to kościoły, kaplice i cmentarze. Zgodnie z nauczaniem Vaticanum II, mają one być przystosowane do sprawowania liturgii oraz ułatwiać wiernym czynny w niej udział ${ }^{46}$. Te miejsca określa KPK w sposób następujący: „Miejscami świętymi są te, które przez poświęcenie lub błogosławieństwo dokonane według przepisów liturgicznych, przeznacza się do kultu Bożego lub na grzebanie wiernych" (kan. 1205).

Dla ożywienia kultu Bożego i wzrostu pobożności ludu chrześcijańskiego Kościół ustanowił czasy święte. Tradycja religijna sięgająca Starego Testamentu poświęcała świętowaniu określone dni i czasy. W tę tradycję włącza się Vaticanum II: „Święta Matka Kościół uważa za swój obowiązek uroczyście celebrować zbawcze dzieło swego Boskiego Oblubieńca przez uświęcone wspomnienie w określone dni całego roku"47. KPK prezentuje dwa rodzaje czasów świętych, jakimi są dni świąteczne i dni pokuty (por. kan. 1246 i 1249).

\section{Zakończenie}

KPK jest narzędziem zbawczej misji Kościoła, gdyż regulując jego potrójną misję: uświęcającą, nauczycielską i pasterską, pomaga w osiągnięciu doskonałości chrześcijańskiej, a tym samym zbawienia. W Kościele - wspólnocie Ludu Bożego wykonywanie misji uświęcającej jest powiązane z misją nauczycielską i pasterską. Stąd kodeksowe unormowanie potrójnej misji Kościoła służy realizacji zasady: „Salus animarum suprema lex esto”.

\footnotetext{
${ }^{46}$ Por. KL, n. $124,128$.

${ }^{47}$ Por. tamże, n. 102.
} 


\section{The role of the Code of Canon Law in fulfilling the mission of the Church}

November 27, 2013 marks the 30th anniversary of coming into effect of the current Code of Canon Law. The law is a very useful tool for the Church community. The Church leads Her people to salvation by exercising threefold office of the Church: teaching, sanctifying, and governing. The code in question regulating munera, is at the service of salvation and accomplishes the principle salus animarum suprema lex. 